\title{
小児前腕骨骨幹部骨折の治療成績
}

$$
\begin{aligned}
& \text { 黒 木 綾 子* 野 口 雅 夫* 过 正 二* } \\
& \text { 銅川 博 文* 黒 木 一 央* }
\end{aligned}
$$

\section{Outcome of Treatment for Forearm Fracture in Children}

\author{
Ayako Kurogi*, Masao Noguchi*, Seiji Tsuji*, \\ Hirofumi Dokawa*, and Kazuhisa Kurogi*
}

\begin{abstract}
小児前腕骨骨折は保存的治療が原則であるが，両骨骨幹部骨折症例では，良好な整復位の獲得が困難な 場合が多い。今回我々は，2000 年 1 月から 2010 年 12 月までに全身麻酔下に徒手整復または観血的治療 を施行した 15 歳以下の前腕両骨骨幹部骨折 19 例を対象とし，治療成績を検討したので報告する。症例は 男児 14 例, 女児 5 例, 平均年齢は 8.6 歳 (2 14 歳), 患側は右 10 例, 左 9 例であった. 平均経過観察 期間は 6.5 力月（3〜16 力月）であつた. 治療法は経皮的鋼線刺入固定が 16 例，プレート固定が 1 例， 徒手整復のみが 2 例であつた。 骨癒合は平均 10.3 週（3 週〜26 週）で得られ，K-wire の骨端線貫通によ る成長障害や変形の発生はなかつた. Grace と Eversmann の評価基準による治療成績は全例優であった が，年長児に髄内釘固定を行い骨癒合が遷延したものが 1 例，外傷後の再骨折が 2 例あつた。
\end{abstract}

Pediatric forearm fractures are usually treated conservatively. However, there is a high incidence of redisplacement and residual angulation of both-bone diaphyseal forearm fractures. We reviewed the clinical results of 19 patients with both-bone diaphyseal forearm fractures treated under general anesthesia from 2000 to 2010. They consistad of 14 male and five female patients with a mean age of 8.6 years (range; 2 to 14 years). The right forearm was injured in 10 children and the left forearm in nine. The average follow-up period was 6.5 months (range; 3 to 16 months). Sixteen patients were treated by percutaneous pin fixation, one by plate fixation, and two by only manual reduction. The average period until bone union was 10.3 weeks (range; 3 to 26 weeks). There were no cases with arm length discrepancies or deformities due to peuetration through the physis. Although clinical results by the Grace \& Eversmann's rating system were excellent in all cases, a 14-year-old boy treated with intramedurally fixation had delayed bone union and two cases suffered refracture.

Key words : pediatric fracture (小児骨折), diaphyseal forearm fracture（前腕骨骨幹部骨折）， surgical treatment（手術治療）

$$
\text { はじめに }
$$

小児前腕骨骨折は保存的治療が原則であるが，両骨 骨幹部骨折症例では，良好な整復位の獲得が困難な場 合が多い。今回我々は，全身麻酔下に徒手整復あるい は観血的治療を行った小児前腕両骨骨折の治療成績を 検討したので報告する.
対象と方法

2000 年以降，当科にて全身麻酔下に徒手整復また は観血的治療を施行した 15 歳以下の前腕両骨骨幹部 骨折 19 例を対象とした。男性 14 例, 女性 5 例, 平均 年齢は 8.6 歳 $(2 \sim 14$ 歳), 患側は右 10 例, 左 9 例で あった. 平均経過観察期間は 6.5 力月 $(3 \sim 16$ 力月) であつた。

骨折部位は前腕骨骨幹部を 3 等分し分類した．近位

\footnotetext{
* 北九州市立八幡病院整形外科 Department of Orthopaedic Surgery, Kitakyushu City Yahata Hospital, Fukuoka, Japan
} 
$1 / 3$ の骨折はなく，中央 $1 / 3$ が 14 例，遠位 $1 / 3$ が 5 例であった。閉鎖性骨折を 18 例, Gustilo Type I の 開放骨折を 1 例認めた.

受傷から全身麻酔下治療までの平均日数は 1.75 日 で，受傷当日が 11 例，翌日が 3 例， 1 週間以内が 4 例, 徒手整復後経過観察中に再転位を来たし受傷 11 日目に観血的治療を行ったものが 1 例であった. 治療 法は観血的治療が 17 例, 徒手整復のみが 2 例であつ た.

手術方法は cross pinning が 2 例, Kirschner wire （以下 K-wire）による䯣内固定が 14 例，プレート固 定が 1 例であった。使用した K-wire は髄腔の大きさ により $1.2 \mathrm{~mm} \sim 2.0 \mathrm{~mm}$ までのものを使用したが， $1.8 \mathrm{~mm}$ を使用した症例が最も多かった。骨端線を $\mathrm{K}$ wire が貫通した症例は 12 例あった。髄内釘固定を 行った症例のうち橈骨逆行性で尺骨順行性のものが 12 例, 橈骨逆行性で尺骨逆行性のものが 2 例, 鋼線 1 本では固定性不良のため髄腔内に 2 本以上鋼線を刺入 した症例は 2 例あつた．手術時に骨折部の観血的整復 を要した症例は 5 例であった。平均外固定期間は 4.9

表 1 Grace と Eversmann の評価基準による治療成績

\begin{tabular}{c|ccc}
\hline \hline 治療成績 & 骨癒合 & & 前腕回旋可動域の健側比 \\
\hline 優 & 有 & and & $90 \%$ 以上 \\
良 & 有 & and & $80 \%$ 以上 \\
可 & 有 & and & $60 \%$ 以上 \\
不可 & 無 & or & $60 \%$ 未満 \\
\hline
\end{tabular}

週（3 週〜16 週） で， 平均内固定期間は 15.4 週（9 週〜32 週) であった.

これらの症例について, 骨癒合期間, 角状変形, 成 長障害，治療成績を調查した。骨癒合はX $\mathrm{X}$ 線上 4 方 向に bridging callus を認めた時とし, 角状変形は近 位骨片の骨軸と遠位骨片の骨軸のなす角を計測した. 治療成績は骨癒合と前腕回旋可動域で評価する Grace と Eversmann の評価基準（表 1）を用いた。

$$
\text { 結果 }
$$

骨瘾合までの期間は平均 10.3 週（3 週〜26 週）で あり，年齢と骨瘑合に要する期間に相関があった（図 1)。角状変形は受傷時単純 $\mathrm{X}$ 線正面像で橈骨は平均 15.6 度, 尺骨は平均 11.8 度, 側面像で橈骨は平均 15.8 度, 尺骨は平均 13.3 度であったが, 最終診察時 単純 X 線正面像では橈骨は平均 1.7 度, 尺骨は平均 0.6 度, 側面像で橈骨は平均 0.8 度, 尺骨は平均 0 度 と良好なアライメントで治癒していた（図 2)。Kwire の骨端線貫通による成長障害や変形の発生はな く, Grace と Eversmann の評価基準による治療成績 は全例優であった，合併症は k-wireが back out し 術後 10 週で $\mathrm{K}$-wire を入れ替えたものが 1 例, 術後 一過性に尺骨神経麻痺を来たしたものが 1 例，骨癒合 が遷延し術後 16 週よりセーフスを使用したものが 1 例, 外傷後の再骨折が 2 例（初回骨折より 8 カ月, 9 カ月後）であった.

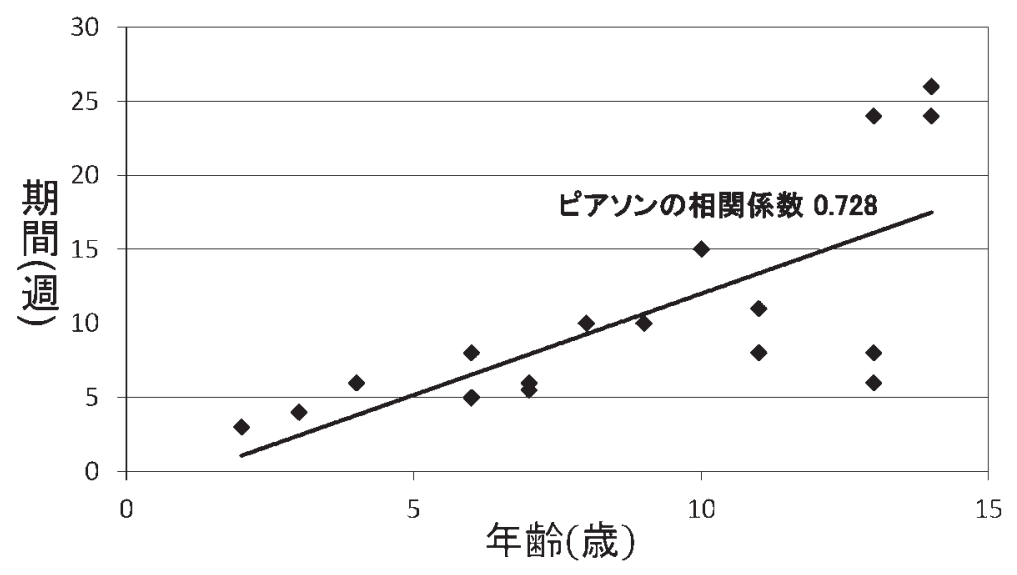

図 1 年齢と骨癒合期間にピアソンの相関係数 0.728 の相関関係がみられた 


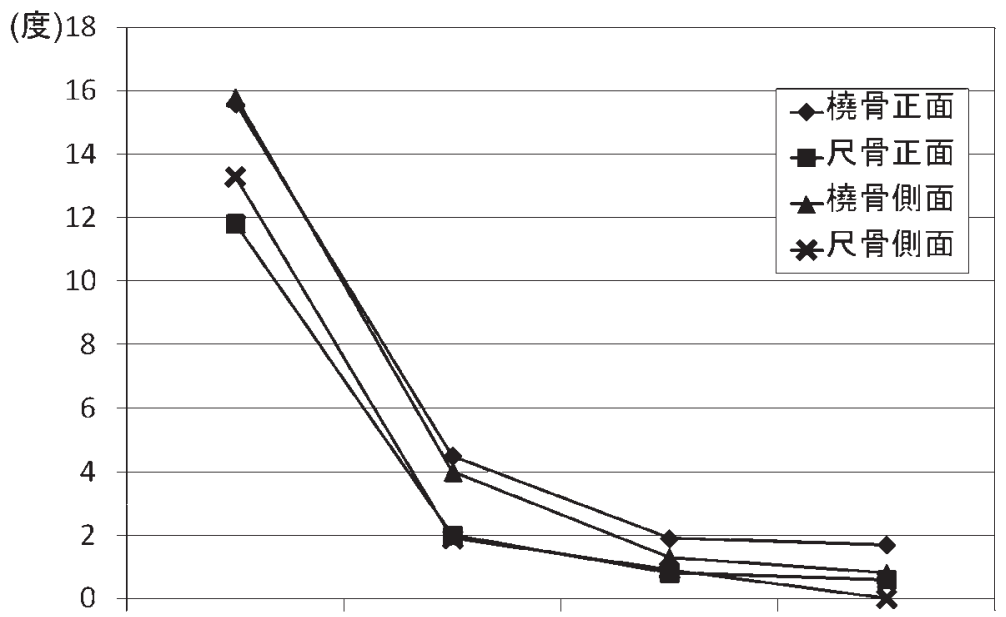

\section{受傷時術直後抜釘時最終診察時}

図 2 角状変形の推移

症

例

症例 1. 14 歳, 男児. 左手を壁に強打し受傷. 骨 幹部中央 $1 / 3$ の完全骨折を認め, 同日経皮的髄内釘 固定を行ったが，側面像にて尺骨骨折部に間隙が残存 していた。このため同部の骨癒合が遷延し，術後 16 週よりセーフスを開始した。術後 26 週で骨癒合し抜 釘を行つた（図 3 ).

症例 2.2 歳，女览．椅子から転落し受傷．骨幹部 中央 $1 / 3$ の若木骨折を認め, 同日経皮的䯣内釘固定 を行つた。術後 3 週間で骨癒合が得られ，術後 15 週 抜釘後の単純 X 線では仮骨の硬化も順調だったが, 骨癒合から 8 力月後に自宅滑り台から転落し再骨折を 来たした。再度経皮的髄内釘固定術を行い，術後経過 は良好である（図 4).

考察

小児前腕両骨骨幹部骨折の治療の目的は前腕回旋機 能の保持である. 小児の骨折という性質上原則として 保存療法を第一選択としているが，転位の状態を正確 に把握し，年齢も加味して治療法を選択する.

角状変形の許容範囲には種々の報告があり，受傷時 の年齢や部位によって異なる.8 歳以上では自家矯正 力は乏しくなり，10 歳を超えると屈曲転位の許容範 囲が非常に小さく，変形と機能障害が遺残し易い ${ }^{2)}$.
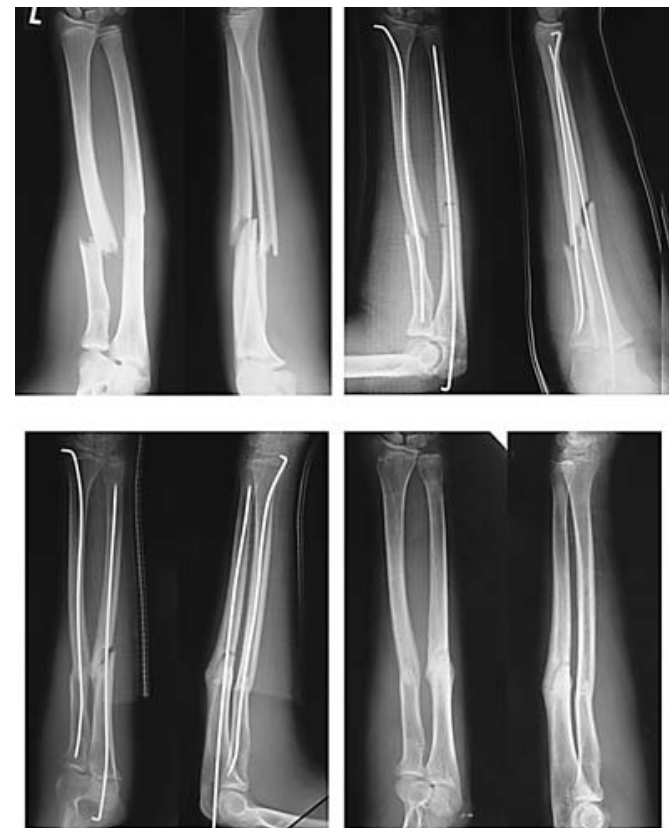

図 3 症例 1
a. 受傷時
b. 術直後
c. 術後 16 週, セーフス開始
d. 術後 28 週, 骨癒合 

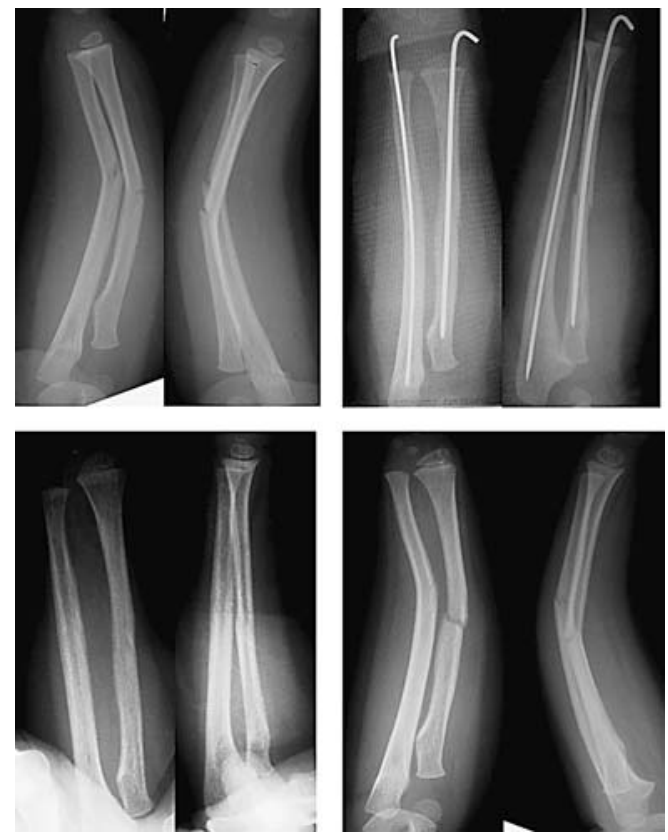

図 4 症例 2
a. 受傷時
b. 術直後
c. 術後 15 週, 抜釘後
d. 術後 9 力月, 再骨折時

一般的に小児の年齢による許容範囲から，回旋変形の ないものでは 10 歳以下では角状変形が掌背屈 $<15^{\circ}$, 橈尺屈 $<15^{\circ}, \quad 11 \sim 13$ 歳では角状変形が掌背屈 $<10^{\circ}$, 橈尺屈 $<5^{\circ}, 13$ 歳以上では角状変形は掌背屈 $<10^{\circ}$ で 橈尺屈変形なしが保存的治療の基準とされている(14)8 .

手術方法は経皮的鋼線刺入固定術が一般的である. その利点として合併症も少なく正確な整復位の保持が 可能であること, 低侵襲であること, 骨膜の温存が可 能であること，抜去が容易であることがあげられる． また，鋼線による骨端線への影響もほとんど認められ ないとの報告がある ${ }^{3)}$. 自験例でも骨端線を K-wire が貫通した症例が 12 例あり，使用した K-wire は 1.2 〜2.0mm, 内固定期間は平均 13 週 (9 24 週) であっ たが, 成長障害や変形の発生はなかった.
年長児においては，骨癒合が遷延することがあり自 家矯正力も低下することなどから，成人と同様にプレ一 卜固定術が推奨されている5 . プレート固定による正 確な整復と強固な内固定により早期運動療法も可能と なる，骨癒合が遷延しセーフスを使用した自験例のよ うに，年長児で正確な整復位の獲得が困難な場合は， プレートでの内固定を検討すべきであると考えられた.

再骨折ついて頻度は $5 \%$ との報告があり ${ }^{7)}$,

Schwarz ら ${ }^{6)}$ は若木骨折の部分的硬化障害が主な原因 で，完全骨折では稀と述べている．自験例では若木骨 折 1 例，完全骨折 1 例に再骨折を認めた. 2 例とも経 過の途中で再骨折発生を危惧させる所見はなく，再骨 折時に明らかな受傷機転があつたが, 骨癒合後の再骨 折の可能性を十分に説明すべきと考えられた.

結語

(1)小児前腕両骨骨折に対し全身麻酔下治療を行つた 19 例 19 肢について治療成績を検討した.

(2)全例で骨癒合が得られ，可動域制限や成長障害は みられなかった。

(3)年長児では成人と同様にプレート固定を検討すべ きであると考えられた.

\section{参 考 文 献}

1）安部吉則ら：小児前腕骨骨幹部骨折の治療. 整・災外, $42: 25-33,1999$.

2）井上＼cjkstart博：前腕骨骨幹部骨折．小览四肢骨折治療の実 際（第 2 版）, pp.185-204. 川井弘光，東京，金原出版， 2001.

3）久賀養一郎ら：小児前腕骨骨折に対する経皮的固定症 例の検討. 整・災外, $48: 508-513,1999$.

4）正富 隆：前腕骨骨折。関節外科, $21 ： 821-827,2002$

5）岡田 潔ら：小児前腕骨折の手術治療成績の検討. 日 手会誌, 23 (3)：301-304, 2006.

6) Shwarz, A.F., et al.: Die refraktur des kindlichen Unterarms. Unfallchirurg, 99 : 175-182, 1996.

7) Shwarz, N., et al.: Refracture of the forearm in children. J. Bone Joint Surg., 78-B : 740-744, 1996.

8）高樋康一郎，三宅潤一，正富 隆：前腕骨骨幹部骨折 に対する保存療法のコツ. MB Orthop., 19(1) : 37-42, 2006. 